\title{
IMPLEMENTASI PROGRAM BPJS KESEHATANDALAM MENINGKATKAN KUALITAS PELAYANAN KESEHATAN DI KOTA TANGERANG
} (Studi padaRumah Sakit Kusta (RSK) Dr. Sitanala Tangerang)

\author{
Effendi', M.Z. Babul Gaos² \\ IUniversitas Muhammadiyah Tangerang, 2STISIP Yuppentek Tangerang \\ EffendiakII@gmail.com
}

Keyword
Implementation, Programs, BPJS
Health Quality Of Health Services

Abstract

This study aims to find out how the influence of the Health BPJS Program Implementation on the quality of health services at Sitanala Leprosy Hospital Dr. The city of Tangerang, with the formulation of the problem: Is there an effect of the implementation of the BPJS health program on the Quality of Health Services at the Leprosy Hospital Dr. Sitanala Tangerang City? The number of samples of 40 techniques used is Random Sampling from 161 populations, the primary data obtained from respondents through a questionnaire. data analysis techniques with regression analysis and static tests (different tests). The results of the statistical test showed that there was a significant effect of the Implementation of the Health BPJS Program on the quality of health services at the Leprosy Hospital Dr. Sitanala Tangerang

\section{PENDAHULUAN}

\section{Latar Belakang Masalah}

Rumah sakit sebagai salah satu fasilitas pelayanan kesehatan diharapkan dapat memberikan pelayanan yang efektif, efisien, dan dituntut untuk memberikan informasi kesehatan yang tepat dalam pelayanan kesehatan dan menghasilkan data yang akurat. Di dalam penyelenggaraan pelayanan publik, masih banyak dijumpai kekurangan, sehingga mempengaruhi kualitas pelayanan kepada masyarakat. Jika kondisi seperti ini tidak direspon, maka akan menimbulkan citra yang kurang baik terhadap rumah sakit sendiri. Mengingat jenis pelayanan yang sangat beragam, maka dalam memenuhi pelayanan diperlukan pedoman yang digunakan sebagai acuan bagi instansi di lingkungan instansi kesehatan. Pelayanan kesehatan adalah hak asasi manusia yang harus diselenggarakan oleh pemerintah dan swasta. Untuk mencapai kualitas yang diharapkan oleh masyarakat perlu adanya kerjasama dan usaha yang berkesinambungan.
Badan Penyelenggara Jaminan Sosial atau BPJS merupakan lembaga yang dibentuk untuk menyelenggarakan Program Jaminan Sosial di Indonesia menurut Undang-undang Nomor 40 Tahun 2004 berisi tentang Sistem Jaminan Sosial Nasional, BPJS merupakan badan hukum nirlaba dan Undang- Undang Nomor 24 Tahun 20II berisi tentang BPJS dibagi 2, BPJS Kesehatan dan BPJS Ketenagakerja, BPJS bertanggungjawab langsung kepada Presiden, BPJS berwenang menagih iuran, menempatkan dana, melakukan pengawasan dan pemeriksaan atas kepatuhan peserta dan pemberi kerja.

Seiring dengan dimulainya JKN per I Januari 20I4, semua program jaminan kesehatan yang telah dilaksanakan pemerintah tersebut (Askes PNS, JPK Jamsostek, TNI, Polri, dan Jamkesmas), diintegrasikan ke dalam satu Badan Penyelenggara Jaminan Sosial Kesehatan (BPJS Kesehatan). Sama halnya dengan program Jamkesmas, pemerintah bertanggungjawab untuk membayarkan iuran JKN bagi fakir miskin dan orang yang tidak mampu yang terdaftar sebagai peserta Penerima Bantuan luran (PBI). 
Untuk mewujudkan derajat kesehatan masyarakat yang optimal. Program JKN di Kota Tangerang merupakan bentuk jaminan kesehatan dari Pemerintah Pusat yang pelaksanaannya berupa pemberian Kartu Asuransi Kesehatan untuk masyarakat agar mereka mendapatkan pelayanan kesehatan berupa pengobatan secara gratis, pemeriksaan kesehatan, dan rawat inap di puskesmas maupun rumah sakit.

Pelayanan kesehatan bagi masyarakat Kota Tangerang dilaksanakan secara berjenjang dimulai dari puskesmas apabila tidak dapat ditangani atau perlu perawatan spesialistik baru dapat dirujuk ke Rumah Sakit yang bekerja sama dengan Pemda Kota Tangerang, kecuali untuk pasien dalam keadaan darurat dapat langsung berobat ke Rumah Sakit melalui IGD (Instalasi Gawat Darurat).

Namun demikian, dalam Pelaksanaan Program JKN di Rumah Sakit Sitanala Kusta (RSK) Dr. Kota Tangerang, masih banyak menghadapi kendala-kendala baik secara internal maupun eksternal. Berbagai permasalahan masih sering ditemui terkait dengan pelayanan yang diberikan, baik karena kurang siapnya kelembagaan pengelola, sumber daya pegawai sebgai pelaksana, maupun ketersediaan anggaran untuk menjalankan program dengan baik. Masalah-masalah tersebut semula diharapkan akan memperoleh bantuan dari pemerintah daerah. Namun secara umum, distribusi tersebut sulit diperoleh karena keterbatasanketerbatasan sumber daya manusia, saranaprasarana dan sebagainya.

Kepuasan pasien adalah indikator utama dari standar suatu fasilitas kesehatan dan merupakan suatu ukuran mutu pelayanan kepuasan pelanggan yang rendah akan berdampak terhadap jumlah kunjungan yang akan mempengaruhi provitabilitas fasilitas kesehatan tersebut, sedangkan sikap karyawan terhadap pelanggan juga akan berdampak terhadap kepuasan pelanggan dimana kebutuhan pelanggan dari waktu ke waktu akan meningkat, begitu pula tuntutannya akan mutu pelayanan yang diberikan. Pengukuran kepuasan pelanggan merupakan elemen penting dalam menyediakan pelayanan yang lebih baik, efisien dan lebih efektif. Tingkat kepuasan pelanggan terhadap pelayanan merupakan faktor penting yang mengembangkan suatu sistem penyediaan pelayanan yang tanggap terhadap keluhan pelanggan, meminimalkan biaya dan waktu serta memaksimalkan dampak pelayanan terhadap pasien.

\section{Rumusan Masalah}

Beranjak dari latarbelakang penelitian, maka selanjutnya permasalahan yang ada dapat dirumuskan sebagai berikut : "Apakah terdapat Hubungan antara implementasi program BPJS kesehatan dengan Kualitas Pelayanan Kesehatan di Rumah Sakit Kusta (RSK) Dr. Sitanala Kota Tangerang?

\section{TINJAUAN PUSTAKA}

\section{Implementasi Kebijakan}

Implementasi yang merupakan terjemahan dari kata "implementation", berasal dari kata kerja "to implement". Menurut Webster's Dictionary (dalam Tachan, 2008: 29), kata to implement berasal dari bahasa Latin "implementum" dari asal kata "impere" dan "plere". Kata "implore" dimaksudkan "to fill up","to fill in", yang artinya mengisi penuh; melengkapi, sedangkan "plere" maksudnya "to fill', yaitu mengisi.

Menurut Nugroho (2006:I25), bahwa implementasi secara administratif adalah implementasi yang dilakukan dalam keseharian operasi dari birokrasi pemerintahan.

Implementasi kebijakan publik dapat dilihat dari beberapa perspektif atau pendekatan. Salah satunya ialah implementation problems approach yang diperkenalkan oleh Edwards III (1980). Edwards III mengajukan pendekatan masalah implementasi dengan terlebih dahulu mengemukakan dua pertanyaan pokok, yakni: (i) faktor apa yang mendukung keberhasilan implementasi kebijakan? dan (ii) faktor apa yang menghambat keberhasilan implementasi kebijakan? Berdasarkan kedua pertanyaan tersebut dirumuskan empat faktor yang merupakan syarat utama keberhasilan proses implementasi, yakni komunikasi, sumber daya, sikap birokrasi atau pelaksana dan struktur organisasi, termasuk tata aliran kerja birokrasi. Empat faktor tersebut menjadi kriteria penting dalam implementasi suatu kebijakan, (Nugroho, $2006:$ 140)

\section{Kebijakan Bidang Kesehatan}

Dengan diberlakukannya Undang-Undang Nomor 17 tahun 2007,tentang Rencana Pembangunan Jangka Panjang Nasional (RPJPN) memberikan arahpembangunan ke depan bagi bangsa Indonesia. Di dalamnya juga tercantum arahpembangunan kesehatan 20 tahun kedepan 
sampai dengan tahun 2025 kemudian ditindak lanjuti oleh Undang-Undang Nomor 24 Tahun $201 \mathrm{I}$ tentang Badan Penyelenggaran Jaminan Sosial, yang mengeluarkan program Jaminan Kesehatan Nasional (JKN) untuk seluruh rakyat Indonesia, agar semua masyarakat mampu menjangkau pelayanan kesehatan yang bermutu secara adil dan merata.

BPJS Kesehatan sebelumnya bernama Askes (Asuransi Kesehatan), yang dikelola oleh PT. Askes Indonesia (Persero), namun sesuai dengan Undang-Undang Nomor 24 Tahun 2011 tentang BPJS, PT. Akses Indonesia berubah menjadi BPJS Kesehatan sejak tanggal I Januari 2014.

Dalam melenium ke tiga ini pembangunan kesehatan dengan pendekatan paradigma sehat menjadi semakin kompleks, berubah dengan cepat dan sering tidak menentu. Menyadari keadaan ini akselersai pembangunan kesehatan yang terarah, saling terkait dan bermakna perlu melandaskan pada prinsip dasar pembangunan kesehatan yang mantap dan konsisten. Prinsip dasar ini meliputi :

I) Perikemanusian yang berlandasakan Ketuhana Yang Maha Esa,

2) Pemberdayaan dan kemandirian setiap orang dan masyarakat,

3) Adil dan merata, yaitu setiap orang mempunyai hak yang sama dalam memperoleh derajat kesehatan yang setinggi-tingginya dan,

4) Pengutamaan serta manfaat, dengan pendekatan sinergisme yang dinamis.

Mengingat kompleksnya pembangunan kesehatan dalam konteks demokratisasi, desentralisasi dan globalisasi, kemampuan penyusunan rencana kebijakan dan program pembangunan kesehatan yang ada perlu lebih ditingkatkan lagi dengan menekankan pentingnya menyusun berbagai skenario atau alternatif. Dengan adanya, I) Dasar-dasar pembangunan kesehatan, 2) Rencana pembangunan jangka panjang bidang kesehatan tahun 2005 - 2025 dan 3) Undang-Undang Nomor 29 Tahun 2011 tentang Badan Penyelenggaran Jaminan Sosial, yang mengeluarkan program Jaminan Kesehatan Nasional (JKN), prospek pembangunan kesehatan diharapkan akan semakin mantap dan merupakan investasi yang penting dalam pembangunan nasional.

\section{Kualitas Pelayanan}

Kata kualitas memiliki banyak definisi yang berbeda dan bervariasi, mulai dari definisi yang konvensional hingga yang strategis. Definisi konvensional dari kualitas biasanya menggambarkan karakteristik langsung dari suatu produk, seperti : performance (kinerja), reability (keandalan), ease of use (mudah dalam penggunaan), esthetics (estetika), dsb. Sedangkan dalam definisi startegis dinyatakan bahwa kualitas adalah sesuatu yang mampu memenuhi keinginan atau kebutuhan pelanggan (meeting the need of costumers). (Sinambela, 2008:6)

Pelayanan publik pada dasarnya adalah pelayanan yang diberikan oleh lembaga publik dalam memenuhi kebutuhan masyarakat akan barang-barang dan jasa. Perbedaan pokok antara pelayanan publik dengan pelayanan dalam bentuk lainnya adalah pelayanan publik ditunjukan untuk meningkatkan kesejahteraan masyarakat dengan biaya sekecilnya. Pelayanan dalam bentuk lainnya selalu bersifat profit oriented yang lebih menekankan pada aspek keuntungan semata.

Karakteristik pelayanan yang berkualitas menurut Triguno (1997: 78) adalah sebagai berikut :

I. Melayani setiap saat.

2. Secara tepat dan memuaskan.

3. Berlaku sopan,

4. Ramah dan menolong,

Profesional dan mampu

Tuntutan perubahan dan kebutuhan masyarakat yang semakin berkembangan telah mengubah definisi dan orientasi kualitas. Dengan bertolak pada konsep putiing first, Costumer driven government,getiingi close to The Customer, kualitas pelayanan bukan lagi ditentukan oleh pemerintah tetapi oleh masyarakat, yang dalam ternologi ekonomi/bisnis disebut sebagai pelanggan. Dengan demikian, penilan tentang kualitas pelayanan bukan berdasarkan pengakuan dari yang memberikan pelayanan, tetapi diberikan oleh langganan atau pihak yang menerima pelayanan (Saeffulah, $2008: 9$ ).

Dalam kaitan itu timbul pertanyaan bagaimana menilai atau mengukur kualitas pelayanan yang diberikan ? dalam perkembangan konsep kualitas, Tjiptono (2004 : 14) sebagai berikut :

I. Tangibles, yakni kualitas pelayanan berupa sarana perkantoran, komputerisasi 
administrasi, ruang tunggu dan tempat informasi.

2. Reliability, yaitu kemampuan dan kehandalan menyediakan pelayanan yang terpercaya.

3. Responsiveness, yaitu kesanggupan membantu dan menyediakan pelayanan secara cepat, tepat serta tanggap terhadap keinginan konsumen.

4. Assurance, yakni kemampuan dan keramahan serta sopan santun aparat dalam meyakini kepercayaan konsumen.

5. Empathy, yaitu sikap tegas tetapi penuh perhatian dari aparat kepada konsumen.

Sinambela, (2008:6) menegaskan bahwa untuk mencapai kepuasan masyarakat dituntut kualitas pelayanan prima yang tercermin dari :

I. Transparansi, yakni pelayanan yang bersifat terbuka, mudah dan dapat diakses oleh semua pihak yang membutuhkan dan disediakan secara memadai serta mudah dimengerti;

2. Akuntabilitas, yakni pelayanan yang dapat dipertanggungjawabkan sesuai dengan ketentuan peraturan perundang-undangan;

3. Kesamaan hak, yaitu pelayanan yang tidak melakukan diskriminasi dilihat dari aspek apapun khususnya suku, ras, agama, status sosial, dan lain-lain;

4. Keseimbangan hak dan kewajiban, yakni pelayanan yang mempertimbangkan aspek keadilan antara pemberi dan penerima pelayanan publik ;

5. Partisipatif, yaitu pelayanan yang dapat mendorong peran serta masyarakat dalam penyelenggaraan pelayanan publik dengan memperhatikan aspirasi, kebutuhan, dan harapan masyarakat;

6. Kondisional, yakni pelayanan yang sesuai dengan kondisi dan kemampuan penerima dan pemberi pelayanan dengan tetap berpegang pada prinsip efisien dan efektivitas.

Berdasarkan dimensi-dimensi kualitas pelayanan diatas, paling tidak terdapat beberapa yaitu Tangibles, yakni kualitas pelayanan berupa sarana perkantoran, peralatan kedokteran, komputerisasi administrasi, ruang tunggu dan tempat informasi. Reliability, yaitu kemampuan dan kehandalan menyediakan pelayanan yang terpercaya. Responsiveness, yaitu kesanggupan membantu dan menyediakan pelayanan secara cepat, tepat serta tanggap terhadap keinginan masyarakat. Assurance, yakni kemampuan dan keramahan serta sopan santun aparat dalam meyakini kepercayaan masyarakat. Empathy, yaitu sikap tegas tetapi penuh perhatian dari aparat kepada masyarakat.

\section{Hipotesis}

Berdasarkan uraian tersebut di atas, maka peneliti membuat hipotesis penelitiannya yaitu: "Terdapat pengaruhsiginifikan Implementasi Program BPJS Kesehatan terhadap kualitas pelayanan kesehatan di Rumah Sakit Kusta (RSK) Dr. Sitanala Tangerang”.

\section{METODE PENELITIAN}

Pada penelitian ini menggunakan moetode kuantitatif. Metode kuantitatif Menurut Sugiyono (2014) mendefinisikan metode penelitian kuantitatif sebagai berikut: "Metode penelitian kuantitatif dapat diartikan sebagai metode penelitian yang berlandaskan pada filsafat positivisme, digunakan untuk meneliti pada populasi atau sampel tertentu, pengumpulan data menggunakan instrumen penelitian, analisis data bersifat kuantitatif/statistik, dengan tujuan untuk menguji hipotesis yang telah ditetapkan”.

\section{Operasional Variabel}

Pada penelitian ini terdiri dari variabel bebas dan variabel terikat.

a. Variabel bebas (independent variabel) disebut variabel pengaruh. Karena variabel bebas mempengaruhi variabel lain. Juga disebut variabel sebab, karena dalam hubungan korasional, variabel bebas menyebabkan munculnya akibat pada varibel lain, simbol yang digunakan adalah $(X)$

b. Variabel terikat (dependent varibel) disebut varibel terikat, karena besaran nilai variabel ini terikat atau tergantung dari nilai varibel bebas. Variabel dependen juga disebut sebagai variabel akibat, karena dalam hubungan korasional, munculnya variabel dependen akibat dari variabel bebas, dan simbol yang digunakan untuk variabel terikat (Y).

Adapun Variabel dalam penelitian ini adalah Implementasi Program BPJS Kesehatan (X) dan Kualitas Pelayanan Kesehatan (X) sebagai variabel dependen.

Operasionalisasi variabel dapat dilihat pada tabel berikut: 
Tabel I. Opersaionalisasi Variabel Penelitian

\begin{tabular}{|c|c|c|c|c|}
\hline No & Variabel Penelitian & Dimensi & Indikator & Item Kuis \\
\hline \multirow{10}{*}{ I } & \multirow{10}{*}{$\begin{array}{c}\text { Implementasi } \\
\text { Program BPJS } \\
\text { Kesehatan } \\
\text { ( Variabel X) }\end{array}$} & \multirow{3}{*}{ I. Komunikasi } & Cara & I \\
\hline & & & Kejelasan & 2 \\
\hline & & & Konsistensi & 3 \\
\hline & & \multirow{4}{*}{ 2. Sumber daya } & Jumlah pegawai & 4 \\
\hline & & & Kompetensi & 5 \\
\hline & & & Sistem informasi & 6 \\
\hline & & & Sarana-prasarana & 7 \\
\hline & & \multirow{2}{*}{ 3. Disposisi } & Sikap & 8 \\
\hline & & & Komitmen & 9 \\
\hline & & 4. Birokrasi & Tupoksi dan SOP & 10 \\
\hline \multirow{12}{*}{2} & \multirow{12}{*}{$\begin{array}{c}\text { Kualitas Pelayanan } \\
\text { Kesehatan }\end{array}$} & \multirow{3}{*}{ I. Tangibles } & Kebersihan & I \\
\hline & & & kenyaman & 2 \\
\hline & & & kelengkapan & 3 \\
\hline & & \multirow{3}{*}{ 2. Reliability } & Prosedur & 4 \\
\hline & & & Pemeriksaan & 5 \\
\hline & & & Penjelasan & 6 \\
\hline & & \multirow[t]{2}{*}{ 3. Responsiveness } & Cepat & 7 \\
\hline & & & Tepat & 8 \\
\hline & & \multirow{3}{*}{ 4. Assurance } & Aman & 9 \\
\hline & & & Terampil & 10 \\
\hline & & & Mutu & II \\
\hline & & 5. Empathy & Sikap & 12 \\
\hline \multicolumn{4}{|c|}{ Jumlah } & 24 \\
\hline
\end{tabular}

Sumber : Sumber: Edward III (1980) dan Tjiptono (2004)

\section{Populasi dan Sampel}

Populasi yang dalam penelitian ini yaitu para pasien yang menggunakan BPJS Kesehatan di Rumah Sakit Kusta (RSK) Dr. Sitanala Tangerang sebanyak 161 pasien peserta JKN.

Arikunto (2008:I I6) menjelaskan, apabila subjeknya kurang dari 100, lebih baik diambil semua sehingga penelitiannya merupakan penelitian populasi. Selanjutnya jika jumlah subjeknya besar dapat diambil antara 10-15\%, atau $20-25 \%$ atau lebih. Sampel pada penelitian ini adalah sebanyak $161 \times 25 \%=40.25$ dibulatkan menjadi 40 orang.

\section{Teknik dan Alat Pengumpulan Data}

Pada penelitian ini penulis menggunakan teknik angket/kuesioner sebagai data primer. Jawaban setiap item instrument padakuesioner yang menggunakan skala likert mempunyai gradiasi dari sangat positif sampai sangat negatif, dan dalam penelitian ini peneliti menggunakan kata-kata antara lain:

Sangat setuju dengan skor 5

Setuju dengan skor 4

Cukup setuju dengan skor 3

Kurang setuju dengan skor 2

Tidak setuju dengan skor I

\section{Teknik Analisis Data}

Data yang terkumpul akan dikategorikan, diklasifikasikan, kemudian dianalisis guna menjawab berbagai pertanyaan-pertanyaan penelitian yang telah disiapkan. Dalam menganalisis data yang digunakan analisis regersi dan uji statistik (uji beda) yang termasuk pada statistik inferensial untuk menguji hipotesis.

Sebelum uji hipotesis dilakukan terlebih dahulu dilakukan uji persyaratan anlisis data yaitu uji validitas, reliablitas dan uji normalitas.

Rancangan uji hipotesis digunakan untuk menguji hipotesis yang diajukan pada penelitian, apakah nilai-nilai statistik yang dihasilkan dari hasil analisis statistik dapat digeneralisasikan terhadap populasi. Pada penelitian ini taraf signifikasi yang digunakan adalah sebesar $5 \%$.

Adapun kriteria pengujian hipotesis adalah sebagai berikut :

I. Jika nilai korelasinya positif $(+)$

Jika nilai $\mathrm{t}$ test $\geq \mathrm{t}$ tabel, maka $\mathrm{H} 0$ ditolak Jika nilai $\mathrm{t}$ test $<\mathrm{t}$ tabel, maka $\mathrm{H} 0$ diterima

2. Jika nilai korelasinya negative ( -$)$

Jika nilai $\mathrm{t}$ test $\leq \mathrm{t}$ tabel, maka $\mathrm{H} 0$ ditolak

jika nilai $\mathrm{t}$ test $>\mathrm{t}$ tabel, maka $\mathrm{HO}$ diterima

\section{HASIL PENELITIAN DAN PEMBAHASAN}

\section{Uji Validitas}

Pengujian validitas data dari jawaban responden dimaksudkan untuk mengetahui, seberapa banyak butir soal dalam kuesioner yang dibagikan ini bersifat valid (sah).

Untuk variabel Implementasi Program BPJS terdapat 10 butir soal yang dibagikan 
kepada 40 responden, sehingga korelasi yang dihasilkan sebanyak 10 korelasi, dan nilai korelasi untuk masing-masing butir soal dapat dilihat dalam tabel berikut :

Tabel 2. Hasil Analisis Uji Validitas Data Variabel Implementasi Program BPJS

\begin{tabular}{|c|c|c|}
\hline No.Item & $\begin{array}{c}\text { Koefisien } \\
\text { Korelasi }\end{array}$ & Keterangan \\
\hline \hline I. & 0,555 & Valid \\
2. & 0,644 & Valid \\
3. & 0,551 & Valid \\
4. & 0,400 & Valid \\
5. & 0,400 & Valid \\
6. & 0,562 & Valid \\
7. & 0,603 & Valid \\
8. & 0,640 & Valid \\
9. & 0,334 & Valid \\
10. & 0,506 & Valid \\
\hline
\end{tabular}

Sumber : Hasil Analisis Data Kuantitatif Kuesioner, Penelitian 2016

Tabel 3. Hasil Analisis Uji Validitas Data Variabel Kualitas Pelayanan Kesehatan

\begin{tabular}{|c|c|c|}
\hline No.Item & $\begin{array}{c}\text { Koefisien } \\
\text { Korelasi }\end{array}$ & Keterangan \\
\hline I. & 0,400 & Valid \\
2. & 0,412 & Valid \\
3. & 0,697 & Valid \\
4. & 0,404 & Valid \\
5. & 0,65 I & Valid \\
6. & 0,663 & Valid \\
7. & $0,46 I$ & Valid \\
8. & 0,506 & Valid \\
9. & 0,566 & Valid \\
I0. & 0,356 & Valid \\
II. & 0,690 & Valid \\
I2. & 0,335 & Valid \\
\hline
\end{tabular}

Sumber : Hasil Analisis Data Kuantitatif Kuesioner, Penelitian 2016

Hasil perhitungan pada tabel 2 dan 3 korelasi tiap butir soal pada variabel Implementasi Program BPJS dan variabel Kualitas Pelayanan Kesehatan, semuanya memiliki nilai korelasi lebih besar daripada 0,3 (nilai kritis), sehingga dapat disimpulkan bahwa semua jawaban responden pada variabel Implementasi Program BPJS 10 butir soal valid dan variabel Kualitas Pelayanan Kesehatan 12 butir soal dinyatakan valid, dan dapat disertakan dalam pengujian lanjutan.

\section{Uji Relibilitas}

Pengujian reabilitas instrumen dilakukan dengan internal consistency dengan teknik belah dua (split half) yang dianalisis dengan rumus Spearman Brown. Untuk keperluan itu maka butir-butir instrumen dibelah menjadi dua kelompok, yaitu kelompok instrumen ganjil dan kelompok instrumen genap. Selanjutnya tiap kelompok itu disusun sendiri. Skor butirnya dijumlahkan sehingga menghasilkan skor total. Kemudian skor total antara ganjil dan genap dicari korelasinya, dan langkah terakhir dengan memasukan nilai korelasi yang diperoleh pada rumus dimasukan ke dalam rumus Spearman Brown, seperti berikut :

$$
r_{i}=\frac{2 r_{b}}{1+r_{b}}
$$

Dengan mengikuti langkah-langkah perhitungan reliabilitas data di atas, maka dapat diketahui hasil reliablitas untuk masing-masing variabel yang disajikan dalam tabel berikut : Tabel 4. Hasil Pengujian Reliabilitas
Data Variabel Penelitian

\begin{tabular}{|c|c|c|c|}
\hline Variabel & $\begin{array}{c}\text { Spearman } \\
\text { Brown }\end{array}$ & $\begin{array}{c}\text { Nilai } \\
\text { Kritis }\end{array}$ & Kesimpulan \\
\hline $\mathrm{X}$ & 0,750 & 0,300 & Data Reliabel \\
\hline $\mathrm{Y}$ & 0,770 & 0,300 & Data Reliabel \\
\hline
\end{tabular}

Sumber : Hasil Analisis Data Kuantitatif Kuesioner, Penelitian 2016

Beradasarkan tabel 4 di atas dapat diketahui bahwa hasil korelasi skor butir ganjil dengan butir genap untuk variabel Implementasi Program BPJS adalah sebesar 0,595, sedangkan untuk variabel Kualitas Pelayanan Kesehatan adalah sebesar 0,620. Atas hasil perhitungan tersebut diperoleh nilai korelasi SpearmanBrownnya sebesar 0,750 untuk variabel Implementasi Program BPJS dan 0,770 untuk variabel Kualitas Pelayanan Kesehatan. Dengan demikian, untuk kedua variabel penelitian keduanya dapat memenuhi syarat untuk dikatakan reliabel, karena hasil perhitungan korelasi sudah lebih besar daripada nilai kritisnya, yaitu 0,300.

\section{Uji Normalitas}

Untuk menguji normalitas data dari masing-masing variabel, peneliti menggunakan software SPSS, yang hasilnya adalah sebagai berikut: 
Tabel 5. Hasil Pengujian Normalitas Data

One-Sample Kolmogorov-Smirnov Test

\begin{tabular}{|ll|r|}
\hline & & $\begin{array}{r}\text { Unstandardized } \\
\text { Residual }\end{array}$ \\
\hline Normal Parameters & Mean & 40 \\
& Std. &, 0000000 \\
& Deviation & 5,54119863 \\
Most Extreme Differences & Absolute &, 093 \\
& Positive &, 093 \\
Kolmogorov-Smirnov Z & Negative &,- 064 \\
Asymp. Sig. (2-tailed) & &, 589 \\
\hline
\end{tabular}

a. Test distribution is Normal.

b. Calculated from data.

Sumber : Output SPSS, Penelitian 2016

Berdasarkan data tabel di atas, maka untuk mengetahui data dari tiap variabel menyebar normal atau tidak, maka dilihat dari output SPSS Kolmogorov-Smirnov Test, diperoleh Asymp. Sig. (2-tailed) adalah 0,878 lebih besar dari 0,05 , sehingga dapat disimpulkan bahwa data yang diuji berdistribusi normal.

\section{Uji Hopitesis}

Uji Regresi Linier

Pengujian regresi dimaksudkan untuk mengetahui kecenderungan perubahan variabel terikat (Kualitas Pelayanan Kesehatan), apabila variabel bebasnya (Implementasi Program BPJS) berubah. Adapun persamaan garis hasil perhitungan yang didapat adalah seperti disajikan dalam tabel berikut:

\section{Tabel 6. Persamaan Garis Regresi Linear Coefficients ${ }^{\mathbf{a}}$}

\begin{tabular}{|c|c|c|c|c|c|c|}
\hline \multirow{2}{*}{\multicolumn{2}{|c|}{ Model }} & \multicolumn{2}{|c|}{ Unstandardized Coefficients } & \multirow{2}{*}{$\begin{array}{c}\text { Standardized } \\
\text { Coefficients }\end{array}$} & \multirow[t]{2}{*}{$\mathrm{t}$} & \multirow[t]{2}{*}{ Sig. } \\
\hline & & $B$ & Std. Error & & & \\
\hline \multirow[b]{2}{*}{1} & (Constant) & 15,709 & 5,276 & & 2,977 & ,005 \\
\hline & $\begin{array}{l}\text { Implementasi Program } \\
\text { BPJS }\end{array}$ & ,751 & , 143 & ,650 & 5,267 & ,000 \\
\hline
\end{tabular}

a. Dependent Variable: Kualitas Pelayanan Kesehatan

Sumber : Output SPSS, Penelitian 2016

Berdasarkan tabel di atas pada output SPSS, persamaan garis linear yang diketahui adalah mempunyai persamaan $\hat{Y}=|5,709+0,75| X$. Untuk memperjelas kecenderungan perubahan nilai variabel terikat yang disebabkan berubahnya variabel bebas pada analisis regresi linear, maka akan mengilustrasikannya melalui gambar berikut ini:

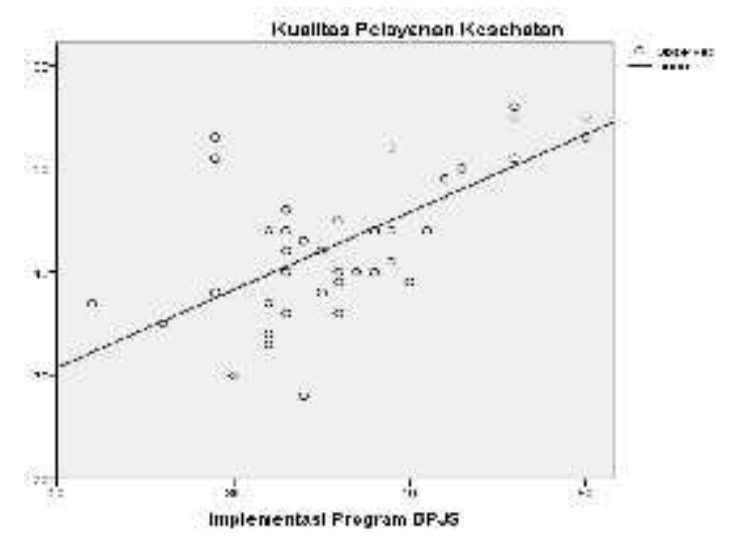

\footnotetext{
Gambar I. Prediksi Variabel Kualitas Pelayanan Kesehatan Dari Hasil Persamaan Garis Regresi Linear
}

Uji Statistik (Uji t)

Berdasarkan tabel 6 diperoleh nilai $t$ hitung sebesar 5,267 bernilai positif dan nilai $t$ tabel sebesar 2,024. Sehingga dapat disimpulkan bahwa $t$ hitung leboh besar dari $t$ tabel, yang berarti $\mathrm{Ha}$ di terima dan Ho ditolak. Hipotesis yang menyatakan : Terdapat pengaruh siginifikan Implementasi Program BPJS Kesehatan terhadap kualitas pelayanan kesehatan di Rumah Sakit Kusta (RSK) Dr. Sitanala Tangerang", terbukti berpengaruh positif dan signifikan pada selang kepercayaan $95 \%$.

\section{Pembahasan}

Berdasarkan hasil perhitungan analisis regresi linear diperoleh sebuah persamaan garis regresi linear yang memenuhi persamaan $\hat{Y}=|5,709+0,75| X$. Model persamaan garis regresi linear ini, menurut peneliti dapat membantu Kepala Rumah Sakit selaku pimpinan organisasi dan pimpinan bidang dalam membuat konsep untuk meningkatkan kualitas pelayanan kesehatan yang diberikan kepada masyarakat pengguna BPJS Kesehatan di RSK Dr. Sitanala Tangerang. 
Dengan mengubah-ubah nilai variabel Implementasi Program BPJS maka besaran target kualitas Kualitas Pelayanan Kesehatan dapat diprediksikan. Sehingga apabila ingin meningkatkan pelayanan kesehatan, maka dapat membantunya dengan meningkatkan (mengubah) Implementasi Program BPJS melalui:

I. Implementasi Program BPJS Kesehatan di RSK Dr. Sitanala disosialisasikan oleh pemerintah penyelenggara program BPJS Kesehatan dengan masif (berkelanjutan) dan sistematis.

2. Sosialisasi program BPJS Kesehatan dilaksanakan secara merata keseluruh unit pelaksana bidang kesehatan baik swasta maupun intansi pemerintahan.

3. Program BPJS Kesehatan selalu dihimbau agar dalam implementasinya pegawai memiliki konsistensi (ketetapan dan kemantapan) dalam melayani kesehatan masyarakat

4. Jumlah pegawai dimasing-masing poli cukup memadai untuk melaksanakan pelayanan kesehatan di RSK Dr. Sitanala

5. Kompetensi pegawai harus memadai dalam melaksanakan tugas pelayanan, sehingga mampu menguasi teknologi dan bekerja secara cepat

6. Sistem informasi penunjang pelayanan kesehatan tersedia dengan baik mengikuti perkembangan teknologi yang handal

7. Sarana-prasarana serta peralatan kedokteran sangat lengkap dan modern sehingga pelayanan kesehatan dapat ditangani dengan baik di RSK Dr. Sitanala

8. Adanya sikap bersungguh-sungguh dengan penuh rasa tanggung jawab dalam melaksanakan tugasnya.

9. Pelaksanakan tugasnya harus sesuai dengan tugas pokok dan fungsinya

10. Setiap pekerjaan selalu sesuai prosedur yang berlaku, baik dalam proses administrasi maupun dalam tindakan praktek kedokteran untuk menangani pasien.

Implementasi program BPJS Kesehatan di

RSK Dr. Sitanala Tangerang sudar berjalan baik, dengan ditunjang tenaga medis atau dokterdokter dan tenaga perawat yang memadai dan memiliki kompetensi dalam memberikan pelayanan kesehatan, adanya kelengkapan instalasi-instalasi yang yang lengkap dan modern, dan ditunjang dengan sarana-parasarana yang lengkap dan berfungsi dengan baik di RSK Dr. Sitanala, sehingga kualitas pelayanan kesehatanpun baik.

\section{PENUTUP}

\section{Kesimpulan}

Berdarakan hasil penelitian, bahwa semakin baik atau meningkatnya implementasi program BPJS Kesehatan yang dilaksanakan oleh RSK Dr. Sitanala Tangerang akan menigkatkan kualitas pelayanan kesehatan.

Pengaruh Implementasi Program BPJS Kesehatan terhadap Kualitas Pelayanan Kesehatan di RSK Dr. Sitanala Tangerang terbukti berpengaruh positif dan siginifikan.

\section{Saran}

I. Program BPJS Kesehatan selalu dihimbau agar dalam implementasinya pegawai memiliki konsistensi (ketetapan dan kemantapan) dalam melayani kesehatan masyarakat

2. Kompetensi pegawai harus memadai dalam melaksanakan tugas pelayanan, sehingga mampu menguasi teknologi dan bekerja secara cepat

3. Sistem informasi penunjang pelayanan kesehatan yang tersedia baiknya mengikuti perkembangan teknologi yang handal

4. Ditingkatkannya sikap bersungguh-sungguh dengan penuh rasa tanggung jawab dalam melaksanakan tugasnya.

5. Pelaksanakan tugasnya harus sesuai dengan tugas pokok dan fungsinya, baik dalam proses administrasi maupun dalam tindakan praktek kedokteran untuk menangani pasien.

6. Perlunya dilakukan penelitian lebih lanjut terakit kualitas pelayanan kesehatan dari variabel-variabel lain yang mempengaruhinya, sehingga dapat diperoleh informasi yang lebih efektif guna menigkatkan kualitas pelayanan kesehatan di RSK Dr. Sitanala Tangerang.

\section{Daftar Pustaka}

Arikunto, Suharsimi. 2002. Prosedur Penelitian. Bina Aksara. Jakarta.

Habib, Rachmat, Hapsara. 2004. Pembangunan Kesehatan di Indonesia : Prinsip Dasar, Kebijakan, Perencanaan dan Kajian Masa Depannya. Yogyakarta. University Press. Kristiadi. J.B. 1996. Prespektif Administrasi Publik Menghadapi Tantangan Abad 2I. Jakarta.

Islamy, M. Irfan, 2009, Prinsip-prinsip Perumusan Kebijaksanaan Negara, Bumi Aksara, Jakarta. 
Moenir, H. A. S. 2002. Manajemen Pelayanan Umum di Indonesia. Jakarta : Bumi Aksara.

Nugroho, D. Riant. 2006. Kebijakan Publik, Formulasi, Implementasi, dan Evaluasi.Jakarta. PT. Elix Media Komputindo.

Saefullah, A.Djadja, 2008. Pemikiran Komteporer Administrasi Publik Perspektif Manajemen Sumber Daya Manusia Dalam Era Desentralisasi, Bandung: LP3AN Fisip UNPAD

Sinambela, Lijan Poltak, 2008. Reformasi Pelayanan Publik: Teori, Kebijakan, dan Implementasi,Jakarta, Penerbit Bumi Aksara.

Sugiyono, 2004. Metode Penelitian Bisnis, Alfabeta: Bandung.

2013. Metode Penelitian

Kombinasi. Alfabeta: Bandung.

Tachan. 2008. Implementasi Kebijakan Publik. Bandung: Peberbit AIPI BandungPuslit KP2W Lemlit Unpad.

Thoha, Miftah, 2000. Perilaku Organisasi Konsep Dasar dan Aplikasinya,PT. Raja Grafindo Persada, Jakarta.

Tjiptono, F. \& Diana, A. 2004 Total Quality Management. Yogyakarta. Andi Ofset.

Undang-Undang Nomor 25 Tahun 2004 tentang Sistem Perencanaan Pembangunan Nasional

Undang-Undang Nomor 17 tahun 2007, tentang Rencana Pembangunan Jangka Panjang Nasional (RPJPN)

Undang-Undang Nomor 24 Tahun 201 I tentang Badan Penyelenggaran Jaminan Sosial (BPJS)

Wahab, Solichin Abdul, 200I/2008, Analisis Kebijaksanaan, Dari Formulasi ke Implementasi Kebijakan Negara, Jakarta: Sinar Grafika.

Winarno. Budi. 2007. Teori dan Proses Kebijakan Publik. Yogyakarta: Media Pressindo. 